\title{
S-02: Venöz Yetmezlikli Hastalarda Kalf Kası Egzersizlerinin Venöz Fonksiyona ve Kas Kuvvetine Etkisi
}

\author{
Sabriye Ercan ${ }^{1}$, Cem Çetin $^{2}$, Turhan Yavuz ${ }^{3}$, Hilmi Mustafa Demir ${ }^{4}$, Yurdagül Baygül Atalay $^{2}$ \\ ${ }^{1}$ Gaziantep Dr. Ersin Arslan Eğitim ve Araştırma Hastanesi, Spor Hekimliği Bölümü, Gaziantep \\ ${ }^{2}$ Süleyman Demirel Üniversitesi, Tıp Fakültesi, Spor Hekimliği AD, Isparta \\ ${ }^{3}$ Süleyman Demirel Üniversitesi, Tıp Fakültesi, Kalp ve Damar Cerrahisi AD, Isparta \\ ${ }^{4}$ Van Eğitim ve Araştırma Hastanesi, Spor Hekimliği Bölümü, Van
}

\section{öz}

Kronik venöz yetmezlik, alt ekstremitenin ilerleyici hipertansiyonu sebebiyle kalf kaslarında zayıflık ile giden bir hastalıktır. Erken tanı ve etkili konservatif tedaviler ile hastalığın ilerleyişi önlenebilir. Venöz geri dönüşü arttırmak ve kalf kas pompasını restore etmek için hastalara egzersiz önerilmektedir.

Bu çalışmanın amacı; kronik venöz yetmezlikli hastalarda, iki farklı kalf egzersizi programının ayak bileği eklem hareket açıklığına, kuvvete, ağrıya, yaşam kalitesine ve venöz geri dolum zamanına etkisini analiz etmekti.

Çalışmaya, kronik venöz yetmezlik tanılı 71 hasta alındı ve hastalar rasgele iki gruba ayrıldı. Ayak bileği eklem hareket açıklığı ölçümünde gonyometre, kas kuvveti ölçümünde izokinetik dinamometre kullanıldı. Venöz geri dolum zamanı, fotopletismografi kullanılarak ölçüldü. Vizüel Analog Skala değeri ağrı seviyesini, EQ-5D genel yaşam kalite ölçeği yaşam kalitesinin seviyesini tanımlamak için uygulandı. 12 hafta boyunca (3 seans/hafta) Grup 1'deki hastalar ev tabanı kalf egzersizlerini, Grup 2'deki hastalar ise aynı egzersizleri ve izokinetik kalf kası egzersizlerini yaptı. Çalışmanın sonunda 42 hastanın kontrol verileri alındı. Kontrol değerleri karşılaştırıldığında gruplar arasında ağrı seviyesi ve kas kuvveti parametrelerinden ayak bileği plantarfleksiyondorsifleksiyon pik tork oranı ve toplam iş parametreleri açısından istatistiksel anlamlı fark tespit edildi $(p<0,05)$. Başlangıç değerleri ile karşılaştırıldığında ise Grup 2'nin tüm ölçümlerinde, Grup $1^{\prime}$ in ayak bileği dorsifleksör pik tork, pik tork/vücut ağırlığı ve venöz geri dolum zamanında istatistiksel anlamlı fark tespit edildi $(p<0,05)$.

Kronik venöz yetmezliği olan hastalarda egzersizin venöz fonksiyonu düzenlemedeki etkisi çalışmamızla bir kez daha ortaya konmuş, izokinetik egzersizin etkisi ise literatürde ilk kez çalışılmıştır.

Bu çalışma, Süleyman Demirel Üniversitesi Araştırma Projeleri Yönetim Birimi tarafından 3618TUI-13 Proje No.su ile desteklenmiştir.

Available at: http://journalofsportsmedicine.org and http://dx.doi.org/10.5152/tjsm.2017.006 